\title{
Hardly Seen and Rarely Heard? European Commission Generated Presence on Polish Social Media
}

\begin{abstract}
This paper discusses the importance of social media as a new channel to communicate European Union activities and policies to the general public. The author examines the fast-growing position of social platforms, such as Facebook, Twitter and YouTube, in the media ecosystem. Their opinion making and agenda setting roles are discussed in the context of deep mediatisation theory - a relatively new, interdisciplinary concept, combining the perspectives of sociology and media sciences.

Based on analysis of the social media activity of the European Commission Representation in Poland, the author examines the Commission's presence in the new channels, within the framework of a new corporate communication campaign, launched in September 2016. The results of the research indicate that that efforts undertaken so far, contrary to intuition, have not yielded a substantial increase in social media activity. However, some promising elements were detected: the quality of users' engagement with the content published by the European Commission has improved.
\end{abstract}

Keywords: European Union, European Commission, communication, media, social media.

\section{Obecność przekazu Komisji Europejskiej w polskich mediach spolecznościowych}

W artykule omówiono rolę mediów społecznościowych jako nowego kanału komunikacji działań i polityk Unii Europejskiej. Autor analizuje szybko rosnącą pozycję platform społecznościowych, takich jak Facebook, Twitter i YouTube, w ekosystemie medialnym. Ich znaczenie w kreowaniu opinii i ustalaniu agendy debaty jest omawiane w kontekście teorii głębokiej mediatyzacji: relatywnie nowej, interdyscyplinarnej koncepcji, łączącej perspektywy socjologii i nauk o mediach.

$\mathrm{Na}$ podstawie analizy aktywności mediów społecznościowych Przedstawicielstwa Komisji Europejskiej w Polsce autor analizuje aktywność KE w nowych kanałach po rozpoczęciu nowej korporacyjnej kampanii komunikacyjnej we wrześniu 2016 r. Wyniki 
badania wskazują, że - wbrew intuicji - znaczący wzrost aktywności Komisji w mediach społecznościowych nie nastąpił. Analiza pozwoliła jednak wychwycić zmianę o pozytywnym charakterze: podniosła się jakość zaangażowania użytkowników w treści publikowane przez Komisję Europejską.

Słowa kluczowe: Unia Europejska, Komisja Europejska, komunikacja, media, media społecznościowe.

\section{Introduction}

The European institutions, like all public bodies in democratic countries, need to inform citizens about their activities, policies and plans. They are obliged to report to the general public and all relevant stakeholders. This task is particularly important for the European Commission, entrusted with the role of guardian of the treaties. ${ }^{1}$ The very first words of Article 17 of the Treaty of the European Union (TEU) state that "the Commission shall promote the general interest of the Union and take appropriate initiatives to that end." Furthermore, the Charter of Fundamental Rights of the European Union gives the citizens the right to be informed. ${ }^{3}$

However, legal obligations are not the only reason for the European bodies - the European Commission in the first place - to engage in a meaningful communication exercise. They should communicate because it is through communication, reaching the general public, that the link between the citizens and the Union is created and reinforced. As some scholars have been pointing out, in the tense political environment beset with referendums on fundamental questions related to the European Union's (EU) most essential matters, the very outlook for European integration hinges on public support. ${ }^{4}$ And this support is built, among other things, on communication.

Institutional communication needs to be efficient to bring the expected, positive results: it needs to reach the right audience with content that impacts recipients' way of thinking and builds trust. The public evaluates the European Union's performance based on their own perception of what the EU delivers. This perception is based on the different incoming signals every member

1 Treaty Of the European Union (consolidated version), art. 17, OJ C 202, 7 June 2016.

2 Ibidem.

3 Charter of Fundamental Rights of the European Union, art. 41(2), art. 42 and art. 27, OJ C 326, 26 October 2012.

4 R. Vliegenthart et al., News Coverage and Support for European Integration 1990-2006, "International Journal of Public Opinion Research" 2008, Vol. 20, No. 4, p. 416. 
of the society receives daily: news, pieces of opinion, etc. As C. de Vreese noted, it is a common knowledge among national political actors that "Many of the traditional structures in national politics are based on this precept - paraphernalia ranging from parliamentary debates to select committee reports are designed to have maximum media impact locally."5 Therefore, the EU institutions' duty is to take the pro-European narrative and deliver it to the public in EU member states, making sure that all relevant facts are presented to citizens. Communication can reassure people - the recipients of the message that things are going in the right direction. It not only restores trust, but it also improves institutional reputation. ${ }^{6}$ Certainly, proper communication is not a magic wand nor a one-fits-all solution, but its importance cannot not be overlooked either. In the past, despite considerable efforts taken, the EU institutions have struggled to generate substantial media coverage. Lack of public acceptance for sharing the financial, humanitarian or geopolitical risks - that is the essence of the European project based on solidarity - was emerging well before the British vote. So was the grassroots backlash against the effects of globalisation and elites, both financial and political. People's frustration had to find its vent. As seasoned European commentator Paul Taylor argued, it would not fade away any time soon. ${ }^{7}$ For a simple reason: the effects of globalisation are here to stay like the gravitational force. The populists have already won some of the communication battles, being able to persuade millions of Europeans that there is an easy escape from the problem. The Brexit referendum was only the most recent (and striking) example of populists' communication efficiency. It illustrates the urgency of a more efficient, counterbalancing, pro-European communication.

In the author's view, the overarching question "how to talk about the EU" should be split into two closely related questions, each meriting separate consideration: "where to talk about the EU" and "what language and tone should be used when talking about the EU."

5 C. de Vreese, Communicating Europe, Foreign Policy Centre, British Council Brussels, 2003, 5, www.files.ethz.ch/isn/22994/Communicating_Europe.pdf (accessed: 13.04.2018).

6 K. Niklewicz, We Need to Talk about the EU: European Political Advertising in the Post-Truth Era, Wilfried Martens Centre for European Studies, Brussels 2017, p. 19.

7 P. Taylor, European History Hovers Close to Reverse Gear, Reuters, www.reuters.com/ article/us-britain-eu-history-analysis-idUSKCN0Z5087? feedType=RSS\&feedName $=$ worldNews\&utm source $=$ Twitter\&utm medium $=$ Social $\&$ utm campaign $=$ Feed $\% 3$ A+Reuters\%2FworldNews+\%28Reuters $+\overline{\text { World}+N e w s \% 29, ~} 16$ VIII 2016 (accessed: 13.04.2018). 
This paper presents the following, preliminary hypothesis: adopting a new communication strategy leads to higher activity in social media, the new dominating channel of communication with the public.

While building the hypothesis, following research questions were asked: What has been the result of the European Commission Representation in Poland's communication activity in social media in recent months (if any) since the launch of the most recent corporate image campaign? What is the main channel for communication with the public opinion? To what extent are the new media (social media, online platforms) critical in the current communication process? How did the EU institutions react to the changing media landscape and, in parallel, to the changing mood of the public? What is the tone of EU narrative in online media in Poland: positive, negative or neutral?

The hypothesis is discussed against the background of the deep mediatisation theory, as presented by N. Couldry and A. Hepp (2017). ${ }^{8}$ Developed in the interdisciplinary field of media sciences and sociology, the theory explains the impact of the internet media (especially the social media) on society and many different social processes, including the political ones. As will be shown in the next section (literature review), the arrival of these social platforms overhauled the media environment and created a new social context. It was the breaking point, the beginning of the deep mediatisation era, as defined by Couldry and Hepp: a time when the nature of the social world becomes dependent upon media content and infrastructure. The deep mediatisation of the current world means it is no longer possible to withdraw from various media interfaces and to exist within the social world (which makes deep mediatisation different from simple mediatisation). ${ }^{9}$

The research presented herein focuses on the communication activity of the European Commission in Poland (European Commission Representation). In the author's view, this geographically limited sample is sufficient for the analysis. The European Commission's media activity in each member state is closely overseen and coordinated by the European Commission Directorate-General Communication and the Spokesperson's Service in Brussels. It is fair to say that the Commission's national social media accounts closely mirror the central social media channels of the European Commission, adapting Brussels-created content to country-specific contexts, especially language-wise. The social media activity of other EU institutions was not investigated. As previously

8 N. Couldry, A. Hepp, The Mediated Construction of Reality, Polity Press, Cambridge 2017.

9 Ibidem, pp. 215-216. 
stated, the Commission leads the EU communication process, not least because of the resources it can allocate to this particular purpose.

\section{Literature Review and Methodology}

Several authors discussed the importance of EU institutions engaging in an efficient communication effort. P. Desmet, J. van Spanje and C. de Vreese analysed the so-called democratic deficit of the European Union and the role of communication in addressing this problem, ${ }^{10}$ while $\mathrm{C}$. Valentini pondered the importance of communication in EU reputation management ${ }^{11}$ and, more generally, in EU public relations. The 2013 study by H.G. Boomgaarden et al., noted that the EU has been (on average) marginally presented in news programmes. ${ }^{12} \mathrm{C}$. de Vreese argued that the long-term goal of the EU should be to promote the very notion of Europe, the image of the EU projecting a "positive, emotionally appealing European narrative, based on European values."13

The consequences of the rise in power of social media have been thoroughly discussed by several authors in the available literature. S. Lindgren observed that digital social platforms like YouTube and Facebook have undoubtedly contributed to a significant transformation of the communication ecosystem. ${ }^{14}$ They may seem unpolitical but, in fact, social platforms have a profound impact on politics and civic activism; they have become an essential engine of political mobilisation. Couldry and Hepp share this observation: their theory argues that within deeply mediatised society, social media profoundly influences most social interactions and provides for new types of political activity. A mere \# (hashtag) can, theoretically, result in a massive, geographically spread campaign with a visible name. Social media allows for an extension of a political process, able to draw in many actors at once, across a broad society. ${ }^{15}$ Also, Couldry and Hepp argue that social media provides

10 P. Desmet, J. van Spanje, C. de Vreese, Discussing the Democratic Deficit: Effects of Media and Interpersonal Communication on Satisfaction with Democracy in the European Union, "International Journal of Communication" 2015, No. 9, pp. 3177-3198.

11 C. Valentini, Political Public Relations in the European Union: EU Reputation and Relationship Management Under Scrutiny, "Public Relations Journal” 2013, Vol. 7, No. 4, pp. 1-13.

12 H.G. Boomgarden et al., Across Time and Space: Explaining Variation in News Coverage of the European Union, "European Journal of Political Research" 2013, No. 52, pp. 606-629.

13 C. de Vreese, Communicating Europe, Foreign Policy Centre, British Council Brussels, 2003, 8, www.files.ethz.ch/isn/22994/Communicating_Europe.pdf, 13 IV 2018 (accessed: 13.04.2018).

14 S. Lindgren, Digital Media \& Society, Sage, London 2018, p. 29.

15 N. Couldry, A. Hepp, The Mediated Construction..., p. 93. 
reference points on which individual and social life is based. ${ }^{16}$ Lindgren underlines that social media, while becoming the place where an average citizen learns the news and shares views, has one unique trait: it facilitates political expression and opinions that are affectively (emotionally) charged. ${ }^{17}$ The latter assumption is crucial to this paper: the more emotional the content is, the faster it propagates.

Analysis of European Commission official documents indicates that it is fully aware of the role of social media. In one of the papers describing the communication strategy for 2017-2018, the Commission admitted that "production of content, including photos, audio-visual, graphics and written material; provision of other corporate technical services which benefit the institution as a whole such as online services, including the institutional web presence and social media activity" 18 is one of the top specific actions that need to be undertaken.

In the past, EU institutions commissioned reports that analysed the efficiency of their communication strategies and implemented projects: a research paper by N. Stroeker, A. van der Graaf and B.-J. Buiskoo ${ }^{19}$ is one of the attempts to define the strengths and weaknesses of the different communication strategies employed by the European Union bodies. However, the topic of EU communication in social media - its shape and impact - has not yet been intensively covered. The author's publication is one of the few examples of research related to this problem..$^{20}$ Also in this vein, Kitchener et al.'s paper, commissioned by the European Commission and published in 2015, provides a detailed overview of the EU's first ever corporate communication campaign ("The EU working for You"), including some data related to the use of social media. Additional insights can be drawn from internal European Commission documents from $2015^{21}$ and $2016 .{ }^{22}$

16 Ibidem, p. 105.

17 Ibidem, p. 142.

18 European Commission, Communication to the Commission from President Juncker and Vice-President Georgieva, Corporate communication action in 2017-2018 under the Multiannual Financial Framework 2014-2020, C(2016) 6838 final, 5.

19 N. Stroeker, A. van der Graaf, B.-J. Buiskool, Communicating "Europe" to Its Citizens: State of Affairs and Prospects, European Parliament, Directorate-General for Internal Policies, Policy Department B: Structural and Cohesion Policy, November 2014, p. 19.

20 K. Niklewicz, We Need to Talk about the EU..., p. 19.

21 European Commission, Communication to the Commission from President Juncker and Vice-President Georgieva, Corporate communication action in 2016 under the Multiannual Financial Framework 2014-2020, C(2015) 7346 final.

22 European Commission, Communication to the Commission from President Juncker and Vice-President Georgieva, Corporate communication action in 2017-2018 under the Multiannual Financial Framework 2014-2020, C(2016) 6838 final. 
The theoretical background for the discussion and the data illustrating the changes in the media environment (presented in the results section) were collected through critical analysis of the available literature. The part focused on the tone of the online narrative about the EU in Poland is based on the Batory Foundation study, published in December 2017.23

The investigation of the recent European Commission presence in social media in Poland (Polish-language profiles: Komisja Europejska (Facebook), @EUinPL (Twitter), Komisja Europejska w Polsce (YouTube) and komisjaeuropejska (Instagram)) follows the author's own research model. In this model, social media presence assessment is based on quantitative appraisal of its different aspects. Within the framework of this model, the following elements were collected: number of posts, videos and pictures published, quality and type of users' reactions and engagement (number of likes, comments and shares). The retrieved data covered the period 1 May 2016-31 March 2018. Data were retrieved using professional social media analysis tools. ${ }^{24}$

\section{Results and Discussion}

As R. Meyer wrote, "Facebook is the 6 o'clock news of the internet: Americans encounter news there not because they're political junkies who seek it out, but because it's presented to them amid statuses, photos, and everything else. More than two-thirds of Americans get their news from social media, and the vast majority of that group uses Facebook." ${ }^{25}$ Although this piece of opinion is somewhat journalistic in style (and published in a news magazine, not a research paper), it aptly describes the role of social media in the current world. The data drawn from the surveys and qualitative research indicate the growing importance of social media, as far the spread and consumption of information and news are concerned. Facebook, YouTube, Twitter and, to a lesser extent, Instagram are becoming one of the primary sources of news and information about the surrounding world.

23 J. Popielawska, J. Szyszko, Narracja o Unii Europejskiej, Fundacja im. Stefana Batorego, December 2017 www.batory.org.pl/upload/files/Programy\%20operacyjne/Otwarta\%20 Europa/Czesc\%201\%20-\%20Narracja\%20o\%20UE.pdf (accessed: 10.04.2018).

24 The tools were made available to the author by Polityka w Sieci Internet consultancy, including proprietary analytical tools and Unamo/Monitori. All data were collected on 5 and 10 April 2018.

25 R. Meyer, Mark Zuckerberg Says He's Not Resigning, "The Atlantic", 9 IV 2018, www.theatlantic.com/technology/archive/2018/04/mark-zuckerberg-atlantic-exclusive/557489 (accessed: 10.04.2018). 
The rising importance of social platforms as communication channels is seen particularly in the United States. In 2017, the Pew Research Center reported that $67 \%$ of Americans declared getting at least some of their news from social media (20\% claimed to do it often) ${ }^{26}$ Compared to 2016 , the newsorientated use of social platforms grew by five percentage points. The results varied substantially in different age cohorts. According to the Pew Research Center, 55\% of Americans aged 50 (or more) declared they learn about news from social media at least sometimes. In the younger cohort (users aged less than 50 years), the number was $78 \%$. Noticeably fewer Americans declare reading (often or sometimes) printed newspapers: $43 \%{ }^{27}$

Similar patterns can be seen in Europe. The Flash Eurobarometer 464, published in March 2018 (general population 15+, 26,576 respondents in total, all EU28 member states covered), showed that $62 \%$ of Europeans (all ages combined) declared using online social networks and messaging apps; 55\% of Europeans claimed to read printed newspapers and news magazines. $61 \%$ of respondents admitted using social platforms at least once a week. ${ }^{28}$ Similar to the US, the Flash Eurobarometer 464 showed that the younger people are, the more often they use social media. ${ }^{29}$ It also showed that a majority of social platform users (56\%) prefer to read or listen to what is shared by others. Analysis of previous polls shows that the number of social media users has grown over the last few years. In November 2015, 50\% of the Europeans polled declared using social networks at least once a week. The Eurobarometer $84,{ }^{30}$ stated the following: "the use of online social networks shows the most significant evolutions: half of Europeans now use them at least once a week, up three percentage points (pp) since the Eurobarometer survey of autumn 2014, 6pp since autumn 2013 and 15 pp since autumn 2011." ${ }^{\prime 1}$

The Polish CBOS survey presents concurring data. For example, in May 2016, 67\% of internet users ( $41 \%$ of all adults) in Poland declared owning a profile on one or more social platforms, five percentage points more than in May 2014. However, among 18-24-year-olds, the share was much more prominent: a record $94 \%$ as of May 2017. In the 25-34-year-old cohort, it was

26 E. Shearer, J. Gottfried, News Use Across Social Media Platforms 2017, Pew Research Center, September 2017.

27 Ibidem.

28 European Commission, Eurobarometer FL464, Fake News and Disinformation Online, March 2018, Table T2.

29 Ibidem, p. 11.

30 Fieldwork in November 2015, published in December 2015.

31 European Commission, Standard Eurobarometer 84, December 2015, 18. 
$86 \%{ }^{32}$ According to the CBOS survey, one-third of all internet users in Poland used social platforms to passively consume content (read articles, etc.). One in four used social platforms to comment on news or any other information. Qualitative studies confirm the conclusions drawn from surveys too. According to research commissioned by the Polish ombudsman in 2017, Polish teenagers consider social platforms as the primary tool for acquiring and verifying information. One of the respondents was quoted as saying, "when I want to find some information about something, I google it or run the YouTube search." 33

Given the background presented earlier, one might expect the European Commission Representation in Poland, like any other public institution obliged to communicate with the general public, would increase its proactive presence on social media and generate content that is best suited to the character of the new, dominant media: one that is emotionally charged. Although Poland is considered to be Euro-enthusiastic, available data suggest that the EU-centred debate in Polish social media is overwhelmingly negative in tone. In the fourth quarter of 2015, in 2016 and in the first three-quarters of 2017 (the period covered by J. Popielawska and J. Szyszko's research), the keywords "Unia Europejska" ("European Union") generated, on average, 745 posts, mentions and comments daily. For comparison, the keyword "uchodźcy" (refugees) generated 1,796 posts, mentions and comments daily. ${ }^{34}$ Pieces of content related to the "European Union" keywords, negative in tone, appeared on screens as much as 178 million times. Positive mentions (posts, comments) were seen 11.3 million times. ${ }^{35}$

Responding to the communication challenge, in September 2016, the European Commission launched a new corporate communication campaign with an essential social media component: the "EU that delivers" project. The college of commissioners gave the go-ahead for this particular campaign in October $2015,{ }^{36}$ the campaign-related activities started in September 2016. The \#investEU hashtag was at the centre of the social media component of the campaign.

32 CBOS, Korzystanie z Internetu, Komunikat z badań nr 49/2017, April 2017, 15.

33 Ł. Jurczyszyn, A. Stefański, Informacja o wynikach badania jakościowego wśród młodzieży na temat: „Różnić się nie oznacza nienawidzić się. Mniej wrogości poprzez wiedzę o prawach człowieka i dialog”, Rzecznik Praw Obywatelskich, 2017, www.rpo.gov. pl/sites/default/files/Raport_z_badan_RPO_Roznic_sie_nie_znaczy_nienawidzic.pdf (accessed: 17.10.2017).

34 J. Popielawska, J. Szyszko, Narracja o Unii..., p. 4.

35 Ibidem, p. 5.

36 European Commission, Communication to the Commission from President Juncker and Vice-President Georgieva, Corporate communication action in 2016 under the Multiannual Financial Framework. 
The goal of the campaign was to streamline European Commission communication around one particular topic: how EU citizens benefit, directly or indirectly, from EU-funded projects. The European Commission Representation in Poland was one of the bodies involved in campaign.

This section presents the data retrieved from the four social media profiles (Facebook, Twitter, Instagram and YouTube) used by the European Commission Representation in Poland, starting in September 2016, when the "EU that delivers" campaign (centred around \#investEU) was launched.

The total number of posts, published by the "Komisja Europejska w Polsce" Facebook page, is presented in Table 1.

Table 1. The Total Number of Posts,

Published by the "Komisja Europejska w Polsce" Facebook Page

\begin{tabular}{|c|c|c|c|c|c|c|c|c|c|c|c|c|c|c|c|c|c|c|c|}
\hline $\begin{array}{l}\text { Month/ } \\
\text { Year }\end{array}$ & \begin{tabular}{|l|} 
IX \\
'16
\end{tabular} & $\begin{array}{l}\mathrm{X} \\
\cdot 16\end{array}$ & \begin{tabular}{|l|}
$\mathrm{XI}$ \\
$\cdot 16$ \\
\end{tabular} & $\begin{array}{l}\text { XII } \\
‘ 6\end{array}$ & $\begin{array}{c}\mathrm{I} \\
17\end{array}$ & $\begin{array}{ll}\text { II } \\
\text { ' } 17\end{array}$ & $\begin{array}{ll}\text { III } \\
' 17\end{array}$ & $\begin{array}{l}\text { IV } \\
\text { '17 }\end{array}$ & $\begin{array}{c}\mathrm{V} \\
\cdot 17\end{array}$ & $\begin{array}{l}\mathrm{VI} \\
117\end{array}$ & $\begin{array}{l}\text { VII } \\
، 17\end{array}$ & $\begin{array}{l}\text { VIII } \\
\text { '17 }\end{array}$ & \begin{tabular}{|l|} 
IX \\
$\cdot 17$
\end{tabular} & \begin{tabular}{|c|}
$\mathrm{X}$ \\
$\cdot 17$
\end{tabular} & \begin{tabular}{|l|}
$\mathrm{XI}$ \\
117
\end{tabular} & \begin{tabular}{|l|} 
XII \\
' 17
\end{tabular} & \begin{tabular}{|c|} 
I \\
'18
\end{tabular} & \begin{tabular}{|l|} 
II \\
'18
\end{tabular} & $\begin{array}{l}\text { III } \\
\text { '18 }\end{array}$ \\
\hline $\begin{array}{l}\text { Number } \\
\text { of Posts }\end{array}$ & 34 & 75 & 20 & 20 & 32 & 19 & 22 & 17 & 28 & 10 & 12 & 3 & 19 & 8 & 6 & 6 & 6 & 29 & 4 \\
\hline
\end{tabular}

Source: author's research.

The number of user comments, posted under the original Facebook posts published by Komisja Europejska w Polsce, is given in Table 2.

Table 2. The Number of User Comments, Posted under the Original Facebook Posts Published by Komisja Europejska w Polsce

\begin{tabular}{|c|c|c|c|c|c|c|c|c|c|c|c|c|c|c|c|c|c|c|c|}
\hline $\begin{array}{l}\text { Month/ } \\
\text { Year }\end{array}$ & $\begin{array}{l}\text { IX } \\
.16\end{array}$ & \begin{tabular}{|c|}
$\mathrm{X}$ \\
.16
\end{tabular} & \begin{tabular}{|l|}
$\mathrm{X} 1$ \\
'16
\end{tabular} & $\begin{array}{l}\text { XII } \\
.16\end{array}$ & $\begin{array}{c}\mathrm{I} \\
.17\end{array}$ & \begin{tabular}{|l|} 
II \\
.17
\end{tabular} & \begin{tabular}{|l|} 
III \\
‘ 17 \\
\end{tabular} & \begin{tabular}{|l|} 
IV \\
.17 \\
\end{tabular} & \begin{tabular}{|l|}
$\mathrm{V}$ \\
$\mathrm{c}$ \\
17
\end{tabular} & \begin{tabular}{|l|} 
VI \\
.17
\end{tabular} & \begin{tabular}{|l|} 
VII \\
'17 \\
\end{tabular} & \begin{tabular}{|l|} 
VIII \\
'17
\end{tabular} & $\begin{array}{l}\text { IX } \\
.17\end{array}$ & \begin{tabular}{|c|}
$\mathrm{X}$ \\
.17
\end{tabular} & \begin{tabular}{|l|}
$\mathrm{XI}$ \\
$\cdot 17$
\end{tabular} & \begin{tabular}{|l|} 
XII \\
$‘ 17$
\end{tabular} & \begin{tabular}{|c|}
$\mathrm{I}$ \\
$\mathrm{r} 18$ \\
\end{tabular} & \begin{tabular}{|l|} 
II \\
.18 \\
\end{tabular} & \begin{tabular}{|l|} 
III \\
‘ 18
\end{tabular} \\
\hline $\begin{array}{l}\text { Number } \\
\text { of Posts }\end{array}$ & 305 & 200 & 123 & 94 & 154 & 178 & 110 & 126 & 266 & 307 & 714 & 305 & 493 & 268 & 230 & 446 & 239 & 256 & 200 \\
\hline
\end{tabular}

Source: author's research.

Another way to assess user engagement on Facebook is to measure the number of "shares" (in other words, how often users share content with their network of friends). The data' is presented in Table 3.

Table 3. The Number of "Shares" on Facebook

\begin{tabular}{|c|c|c|c|c|c|c|c|c|c|c|c|c|c|c|c|c|c|c|c|}
\hline Month/ & IX & $\mathrm{X}$ & $\mathrm{X} 1$ & XII & I & II & III & IV & V & VI & VII & VIII & IX & $\mathrm{X}$ & XI & XII & I & II & III \\
\hline Year & '16 & ' 16 & ‘6 & '16 & '17 & '17 & ‘ 17 & ‘ 17 & ' 17 & '17 & '17 & '17 & '17 & '17 & '17 & '17 & '18 & ' 18 & 18 \\
\hline $\begin{array}{l}\text { Number } \\
\text { of Posts }\end{array}$ & 82 & 188 & 74 & 44 & 121 & 43 & 89 & 33 & 205 & 19 & 134 & 5 & 96 & 18 & 105 & 6 & 49 & 85 & 11 \\
\hline
\end{tabular}

Source: author's research.

Counting the "likes" (how often users click the "like" button under any given post published on the page) is yet another way to assess users' attitude towards the content. The data is presented in Table 4 . 
Table 4. The Number of "Likes" on Facebook

\begin{tabular}{|c|c|c|c|c|c|c|c|c|c|c|c|c|c|c|c|c|c|c|c|}
\hline $\begin{array}{l}\text { Month / } \\
\text { Year }\end{array}$ & $\begin{array}{l}\text { IX } \\
\cdot 16\end{array}$ & $\begin{array}{c}\mathrm{X} \\
16\end{array}$ & $\begin{array}{l}\mathrm{X} 1 \\
16\end{array}$ & $\begin{array}{l}\text { XII } \\
، 16\end{array}$ & $\begin{array}{c}\mathrm{I} \\
\mathrm{\prime} 17\end{array}$ & $\begin{array}{l}\text { II } \\
\text { '17 }\end{array}$ & $\begin{array}{l}\text { III } \\
' 17\end{array}$ & $\begin{array}{l}\text { IV } \\
117\end{array}$ & $\begin{array}{c}\mathrm{V} \\
17\end{array}$ & $\begin{array}{l}\text { VI } \\
' 17\end{array}$ & \begin{tabular}{|l|} 
VII \\
$' 17$
\end{tabular} & \begin{tabular}{|l|} 
VIII \\
$' 17$
\end{tabular} & $\begin{array}{l}\text { IX } \\
117\end{array}$ & $\begin{array}{c}\mathrm{X} \\
\cdot 17\end{array}$ & $\begin{array}{l}\mathrm{XI} \\
\cdot 17\end{array}$ & $\begin{array}{l}\text { XII } \\
\cdot 17\end{array}$ & $\begin{array}{c}\mathrm{I} \\
18\end{array}$ & $\begin{array}{r}\text { II } \\
18\end{array}$ & $\begin{array}{l}\text { III } \\
\text { '18 }\end{array}$ \\
\hline $\begin{array}{l}\text { Number } \\
\text { of Likes }\end{array}$ & 997 & 774 & 371 & 301 & 482 & 420 & 584 & 719 & 1203 & 352 & 3728 & 2013 & 1149 & 497 & 443 & 2196 & 369 & 618 & 253 \\
\hline
\end{tabular}

Source: author's research.

The European Commission Representation in Poland also runs the Twitter profile@EUinPL. Due to the particular characteristics of this social platform, the number of posts published is substantially more significant, compared to Facebook. Data are presented in Table 5.

Table 5. The Number of Posts Published on the Twitter Profile @EUinPL

\begin{tabular}{|c|c|c|c|c|c|c|c|c|c|c|c|c|c|c|c|c|c|c|c|}
\hline $\begin{array}{l}\text { Month } \\
\text { Year }\end{array}$ & \begin{tabular}{|l|} 
IX \\
$\cdot 16$ \\
\end{tabular} & $\begin{array}{c}\mathrm{X} \\
\cdot 16 \\
\end{array}$ & $\begin{array}{l}\mathrm{X} 1 \\
\text { ‘ } 16 \\
\end{array}$ & \begin{tabular}{|l|} 
XII \\
‘16 \\
\end{tabular} & \begin{tabular}{|c|}
$\mathrm{I}$ \\
$\cdot 17$ \\
\end{tabular} & \begin{tabular}{|c|} 
II \\
‘ 17 \\
\end{tabular} & \begin{tabular}{|l|} 
III \\
'17 \\
\end{tabular} & \begin{tabular}{|l|} 
IV \\
'17 \\
\end{tabular} & \begin{tabular}{|c|}
$\mathrm{V}$ \\
$\cdot 17$ \\
\end{tabular} & $\begin{array}{l}\text { VI } \\
، 17 \\
\end{array}$ & $\begin{array}{l}\text { VII } \\
\cdot 17 \\
\end{array}$ & $\begin{array}{l}\text { VIII } \\
\text { '17 } \\
\end{array}$ & \begin{tabular}{|l} 
IX \\
$، 17$ \\
\end{tabular} & $\begin{array}{c}\mathrm{X} \\
\cdot 17 \\
\end{array}$ & \begin{tabular}{|l}
$\mathrm{XI}$ \\
$، 17$ \\
\end{tabular} & \begin{tabular}{|l|} 
XII \\
$‘ 17$ \\
\end{tabular} & \begin{tabular}{|c|} 
I \\
18 \\
\end{tabular} & $\begin{array}{r}\text { II } \\
\text { '18 } \\
\end{array}$ & \begin{tabular}{|l} 
III \\
‘ 18 \\
\end{tabular} \\
\hline $\begin{array}{l}\text { Number } \\
\text { of Posts }\end{array}$ & 198 & 182 & 147 & 139 & 157 & 14 & 278 & 15 & 164 & 115 & 88 & 27 & 149 & 155 & 88 & 91 & 65 & 97 & 4 \\
\hline
\end{tabular}

Source: author's research.

User engagement on the @EUinPL profile (number of comments, "likes" and retweets - the Twitter equivalent of the FB "share") can be assessed by the following data presented in Table 6 .

Table 6. The Number of Comments, "Likes" and Retweets on the @EUinPL Profile

\begin{tabular}{|c|c|c|c|c|c|c|c|c|c|c|c|c|c|c|c|c|c|c|c|}
\hline $\begin{array}{l}\text { Month/ } \\
\text { Year }\end{array}$ & $\begin{array}{l}\text { IX } \\
16\end{array}$ & $\begin{array}{c}\mathrm{X} \\
\cdot 16\end{array}$ & $\begin{array}{l}\text { XI } \\
\text { ‘16 }\end{array}$ & $\begin{array}{l}\text { XII } \\
16\end{array}$ & $\begin{array}{c}\mathrm{I} \\
\cdot 17\end{array}$ & $\begin{array}{l}\text { II } \\
، 17\end{array}$ & $\begin{array}{l}\text { III } \\
‘ 17\end{array}$ & $\begin{array}{l}\text { IV } \\
\text { '17 }\end{array}$ & $\begin{array}{c}\mathrm{V} \\
\cdot 17\end{array}$ & $\begin{array}{l}\text { VI } \\
\text { '17 }\end{array}$ & \begin{tabular}{|l|} 
VII \\
'17
\end{tabular} & $\begin{array}{l}\text { VIII } \\
\text { '17 }\end{array}$ & $\begin{array}{l}\text { IX } \\
\text { '17 }\end{array}$ & $\begin{array}{c}\mathrm{X} \\
17\end{array}$ & $\begin{array}{l}\text { XI } \\
\text { '17 }\end{array}$ & \begin{tabular}{|l|} 
XII \\
‘ 17
\end{tabular} & $\begin{array}{c}\mathrm{I} \\
18\end{array}$ & $\begin{array}{r}\text { II } \\
\text { '18 }\end{array}$ & $\begin{array}{l}\text { III } \\
\text { '18 }\end{array}$ \\
\hline ments & 21 & 230 & 168 & 162 & 138 & 148 & 355 & 171 & 252 & 130 & 479 & 41 & 357 & 613 & 340 & 442 & 415 & 162 & 317 \\
\hline Likes & 404 & 204 & 262 & 287 & 298 & 226 & 634 & 249 & 432 & 192 & 834 & 55 & 490 & 958 & 361 & 372 & 416 & 200 & 479 \\
\hline Retweets & 287 & 198 & 162 & 145 & 140 & 139 & 338 & 161 & 239 & 111 & 491 & 23 & 304 & 425 & 358 & 154 & 265 & 154 & 261 \\
\hline
\end{tabular}

Source: author's research.

The European Commission Representation in Poland apparently deprioritised its activity on Instagram (the picture-sharing social media platform). As shown in Table 7, the number of posts published in 2017 and at the beginning of 2018 was substantially lower than in 2016.

Table 7. The Number of Posts, Comments and Likes on Instagram

\begin{tabular}{|c|c|c|c|c|c|c|c|c|c|c|c|c|c|c|c|c|c|c|c|}
\hline $\begin{array}{l}\text { Month / } \\
\text { Year }\end{array}$ & $\begin{array}{l}\text { IX } \\
\cdot 16\end{array}$ & $\begin{array}{c}\mathrm{X} \\
\cdot 16\end{array}$ & $\begin{array}{l}\mathrm{XI} \\
\cdot 16\end{array}$ & $\begin{array}{l}\text { XII } \\
16\end{array}$ & $\begin{array}{c}\mathrm{I} \\
\cdot 17\end{array}$ & II 17 & \begin{tabular}{|l|} 
III \\
$‘ 17$
\end{tabular} & IV & $\begin{array}{c}\mathrm{V} \\
17\end{array}$ & $\begin{array}{l}\text { VI } \\
، 17\end{array}$ & $\begin{array}{l}\text { VII } \\
\text { ‘17 }\end{array}$ & \begin{tabular}{|l|} 
VIII \\
$\cdot 17$
\end{tabular} & $\begin{array}{l}\text { IX } \\
\cdot 17\end{array}$ & $\begin{array}{c}\mathrm{X} \\
117\end{array}$ & \begin{tabular}{|l|}
$\mathrm{XI}$ \\
$\cdot 17$
\end{tabular} & $\begin{array}{l}\mathrm{XII} \\
\cdot 17\end{array}$ & $\begin{array}{c}\mathrm{I} \\
18\end{array}$ & $\begin{array}{r}\text { II } \\
18\end{array}$ & $\begin{array}{l}\text { III } \\
\text { '18 }\end{array}$ \\
\hline Posts & 19 & 9 & 7 & 5 & 12 & 6 & 14 & 6 & 14 & 1 & 2 & 0 & 6 & 2 & 2 & 0 & 6 & 8 & 2 \\
\hline $\begin{array}{l}\text { Com- } \\
\text { ments }\end{array}$ & 17 & 22 & 13 & 34 & 20 & 6 & 33 & 13 & 30 & 15 & 28 & 28 & 20 & 10 & 25 & 42 & 14 & 58 & 24 \\
\hline "Likes" & 504 & 1482 & 267 & 914 & 553 & 269 & 1862 & 364 & 826 & 515 & 503 & 1332 & 588 & 217 & 1124 & 785 & 418 & 1589 & 759 \\
\hline
\end{tabular}

Source: author's research. 
Due to technical constraints (the limitations of the tools used), data from the YouTube profile of the European Commission Representation in Poland was collected only for the period January 2017 - March 2018. The following data was retrieved: the number of videos published, the number of views and users' reaction (number of times the "thumbs up/down" buttons were clicked). Results are presented in Table 8.

Table 8. Date from the YouTube Profile of the European Commission Representation in Poland

\begin{tabular}{|c|c|c|c|c|c|c|c|c|c|c|c|c|c|c|c|}
\hline $\begin{array}{l}\text { Month / } \\
\text { Year }\end{array}$ & $\begin{array}{c}\mathrm{I} \\
17\end{array}$ & $\begin{array}{r}\text { II } \\
17\end{array}$ & $\begin{array}{l}\text { III } \\
' 17\end{array}$ & $\begin{array}{l}\text { IV } \\
\text { '17 }\end{array}$ & $\begin{array}{c}\mathrm{V} \\
17\end{array}$ & $\begin{array}{l}\text { VI } \\
17\end{array}$ & $\begin{array}{l}\text { VII } \\
\text { '17 }\end{array}$ & $\begin{array}{l}\text { VIII } \\
' 17\end{array}$ & $\begin{array}{l}\text { IX } \\
\text { '17 }\end{array}$ & $\begin{array}{c}\mathrm{X} \\
117\end{array}$ & $\begin{array}{l}\mathrm{XI} \\
' 17\end{array}$ & $\begin{array}{l}\text { XII } \\
' 17\end{array}$ & $\begin{array}{c}\mathrm{I} \\
' 18\end{array}$ & $\begin{array}{l}\text { II } \\
\text { '18 }\end{array}$ & $\begin{array}{l}\text { III } \\
' 18\end{array}$ \\
\hline Videos Posted & 1 & 1 & 4 & 3 & 6 & 0 & 2 & 1 & 3 & 3 & 6 & 10 & 7 & 1 & 7 \\
\hline Views & 34 & 57 & 992 & 704 & 4473 & 0 & 101 & 193 & 832 & 425 & 358 & 457 & 236 & 100 & 559 \\
\hline $\begin{array}{l}\begin{array}{l}\text { Thumbs up } \\
\text { ("Likes") }\end{array} \\
\text { (Likes }\end{array}$ & 0 & 3 & 11 & 1 & 54 & 0 & 3 & 4 & 11 & 1 & 9 & 15 & 11 & 1 & 11 \\
\hline $\begin{array}{l}\text { Thumbs down } \\
\text { ("Dislikes") }\end{array}$ & 1 & 1 & 9 & 1 & 7 & 0 & 2 & 0 & 2 & 6 & 6 & 5 & 0 & 0 & 0 \\
\hline
\end{tabular}

Source: author's research.

Between January 2017 and March 2018, the European Commission Representation in Poland published five videos with the \#investEU hashtag embedded. In total, these five videos were viewed 110 (one hundred and ten) times. For comparison, the video entitled "Wrocławianie ratują kaczki (-)" ("Citizens of Wrocław save the ducks (-)") was viewed 1,849 times.

Analysis of all the social media profiles run by the European Commission Representation in Poland revealed that, indeed, the number of posts with the hashtag \#investEU included in the body of the text has been increasing gradually. In September 2016, analytical tools detected 27 publications with the \#investEU in all investigated social platforms. In October, November and December there were 12, 37 and 14, respectively. The numbers rose in 2017: the \#investEU hashtag was posted 21 times in January, 30 times in February and 49 in March, only to drop to 12 in April. The end of 2017 brought a surge in the number of social media posts with \#investEU included in the body of the content: 249 items published in October, 97 in November and 135 in December 2017. The average for the first quarter of 2018 was 95. Moreover, additional research revealed that posts tagged with \#investEU generated uneven user engagement. Until July 2017, the number of comments published below the original posts (tagged \#investEU) did not exceed 70 per month on average. In the period July-December 2017, the number of comments posted below the original content tagged \#investEU spiked to 523 per month on average. 
Collected results do not show a substantial change in European Commission (its Polish representation) social media activity, contrary to what one might expect from the launch of the corporate communication campaign. Data retrieved from the four leading social media platforms showed no substantial increase in the number of posts (pictures, videos) published after September 2017. Take the Facebook profile, as an example. In September 2016, Komisja Europejska w Polsce profile issued 34 posts; in the following month -75 . One year later, the number of items published dropped to 19 and 8, respectively. The same pattern can be seen on the @EUinPL Twitter account. Contrary to what might be expected, the number of posts published in the fourth quarter of 2016 was more significant than in fourth quarter of 2017 (468 to 369). As shown in the Results section, the same pattern was detected on the Instagram profile of the European Commission Representation in Poland. Apparently, the start of the corporate campaign "EU that delivers" did not translate into more prominent activity, as measured by the number of posts published on different social media platforms. Identifying the reasons for this relative stagnation of the social media activity of the European Commission (EC) Representation to Poland goes beyond the scope of this research. However it is worth noting that the topic merits further investigation.

On the other hand, the social media activity of the EC Representation to Poland could have impacted (albeit with a delay) the intensity and the quality of user engagement. This correlation is implied by the number of comments, published under the Komisja Europejskaw Polsce/@EUinPL original social media posts.

Yet the picture is far from crystal clear. Detailed analysis of the videos published on the Commission's YouTube profile suggests that the content focused on \#investEU hasn't generated significantly higher user engagement. On the contrary, videos related to the \#investEU theme were less popular than the apparently more entertaining video "Citizens of Wrocław save ducks" or "Europe means us: let's talk about it." It suggests that the content created for the corporate campaign, anchored around \#investEU, did not strike the right emotional note.

\section{Conclusions}

The European Commission seems to be aware of the growing importance of social media as the new, essential communication channel. One of the assumptions embedded with the Commission's most recent corporate image campaign was to focus on specific content for platforms like Facebook, Twitter 
or YouTube. Symbolically, the reference point for the corporate campaign the hashtag \#investEU - is, in itself, a characteristic element of communication via social media (hashtags are widely used on Twitter, Instagram and, to some extent, on Facebook).

However, the research conducted for this paper plainly indicated that, at least in the Polish case, the abovementioned acknowledgement of the role of social media did not necessarily translate into any more significant activity.

This paper's hypothesis was not fully confirmed. Regardless of the intentions, the results of European Commission Representation presence on social media in Poland, after September 2016 (when the corporate image campaign started), were limited at best. The quality of social media user engagement improved (as measured by the number of reactions), but the activity, as measured by the number of items published, flattened if not decreased. As the case of the YouTube profile of the European Commission Representation in Poland shows, the campaign-related content did not stir emotions, which implies it was incorrectly created.

On a final note, the author believes that further, more complex research is urgently needed to better analyse the current presence of the European Commission (and, eventually, other EU institutions) on social media. In particular, additional research is needed to understand possible flaws in the new EC corporate image campaign, including reasons for the lower than expected social media activity, insufficient quality, lack of an emotional message, etc. Preferably, such research should encompass all EU member states to broaden the scope and verify the findings presented in this paper.

The author wishes to express his gratitude to Michat Fedorowicz and Lukasz Kotelski of "Polityka $w$ Sieci" internet consultancy for their valuable help in the process of data gathering.

\section{Bibliography}

Boomgarden H.G. et al., Across Time and Space: Explaining Variation in News Coverage of the European Union, "European Journal of Political Research" 2013, No. 52.

CBOS, Korzystanie z Internetu, Komunikat z badań nr 49/2017, April 2017.

Charter of Fundamental Rights of the European Union, art. 41(2), art. 42 and art. 27, OJ C 326, 26 October 2012.

Couldry N., Hepp A., The Mediated Construction of Reality, Polity Press, Cambridge 2017. de Vreese C., Communicating Europe, Foreign Policy Centre, British Council Brussels, 2003, 8, www.files.ethz.ch/isn/22994/Communicating_Europe.pdf. 
Desmet P., Spanje J. van, de Vreese C., Discussing the Democratic Deficit: Effects of Media and Interpersonal Communication on Satisfaction with Democracy in the European Union, "International Journal of Communication" 2015, No. 9.

European Commission, Eurobarometer FL464, Fake News and Disinformation Online, March 2018.

Jurczyszyn Ł., Stefański A., Informacja o wynikach badania jakościowego wśród młodzieży na temat: "Różnić się nie oznacza nienawidzić się. Mniej wrogości poprzez wiedzę o prawach człowieka i dialog”, Rzecznik Praw Obywatelskich, 2017, www.rpo.gov.pl/ sites/default/files/Raport_z_badan_RPO_Roznic_sie_nie_znaczy_nienawidzic.pdf.

Lindgren S., Digital Media \& Society, Sage, London 2017.

Meyer R., Mark Zuckerberg Says He's Not Resigning, "The Atlantic”, 9 IV 2018, www.theatlantic.com/technology/archive/2018/04/mark-zuckerberg-atlantic-exclusive/557489.

Niklewicz K., We Need to Talk about the EU: European Political Advertising in the Post-Truth Era, Wilfried Martens Centre for European Studies, Brussels 2017.

Popielawska J., Szyszko J., Narracja o Unii Europejskiej, Fundacja im. Stefana Batorego, December 2017, www.batory.org.pl/upload/files/Programy\%20operacyjne/Otwarta\%20 Europa/Czesc\%201\%20-\%20Narracja\%20o\%20UE.pdf.

Shearer E., Gottfried J., News Use Across Social Media Platforms 2017, Pew Research Center, September 2017.

Stroeker N., van der Graaf A., Buiskool B.-J., Communicating “Europe” to Its Citizens: State of Affairs and Prospects, European Parliament, Directorate-General for Internal Policies, Policy Department B: Structural and Cohesion Policy, November 2014.

Taylor P., European History Hovers Close to Reverse Gear, Reuters, www.reuters.com/article/ us-britain-eu-history-analysis-idUSKCN0Z5087? feedType=RSS\&feedName=worldNew s\&utm_source $=$ Twitter\&utm_medium $=$ Social\&utm_campaign $=$ Feed $\% 3 \mathrm{~A}+$ Reuters $\% 2 \mathrm{Fw}$ orldNews+\%28Reuters+World+News\%29.

Treaty of the European Union (consolidated version), art. 17, OJ C 202, 7 June 2016.

Valentini C., Political Public Relations in the European Union: EU Reputation and Relationship Management Under Scrutiny, "Public Relations Journal" 2013, Vol. 7, No. 4.

Vliegenthart R. et al., News Coverage and Support for European Integration 1990-2006, "International Journal of Public Opinion Research" 2008, Vol. 20, No. 4. 